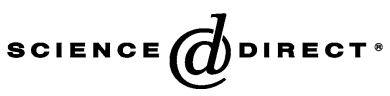

Life Sciences 77 (2005) 1094-1105
Life Sciences

www.elsevier.com/locate/lifescie

\title{
Differential effects of ethanol ingestion on somatostatin content, somatostatin receptors and adenylyl cyclase activity in the frontoparietal cortex of virgin and parturient rats
}

\author{
Vicente Barrios ${ }^{\mathrm{a}, *}$, Lilian Puebla-Jiménez ${ }^{\mathrm{b}}$, María del Carmen Boyano-Adánez ${ }^{\mathrm{b}}$, \\ Manuel Sanz ${ }^{c}$, Leandro Soriano-Guillén ${ }^{\mathrm{a}}$, Eduardo Arilla-Ferreiro ${ }^{\mathrm{b}}$ \\ ${ }^{a}$ Research Laboratory, Universidad Autónoma, Hospital Infantil Universitario Niño Jesús, Avda. Menéndez Pelayo, \\ 65; 28009 Madrid, Spain \\ ${ }^{\mathrm{b}}$ Neurobiochemistry Unit, Department of Biochemistry and Molecular Biology, Faculty of Medicine, Universidad de Alcalá, \\ Alcalá de Henares, E-28871 Madrid, Spain \\ ${ }^{\mathrm{c}}$ Surgery Unit II, Hospital Clínico San Carlos, Universidad Complutense, Madrid, Spain
}

Received 18 October 2004; accepted 10 January 2005

\begin{abstract}
Chronic ethanol ingestion decreases the number of somatostatin (SRIF) receptors in the rat frontoparietal cortex and female sex hormones modulate the effects of ethanol in the brain. Therefore, we investigated the differential effects of ethanol consumption on the SRIFergic system in the frontoparietal cortex of virgin and parturient rats given ethanol in their drinking water before and during gestation. In parturient rats, ethanol consumption decreased the density of SRIF receptors $(25 \%, \mathrm{p}<0.01$ vs control parturient group) whereas the SRIF-like immunoreactivity (SRIF-LI) content was increased $(140 \%, \mathrm{p}<0.01)$. In virgin rats, ethanol ingestion decreased the density of SRIF receptors $(42 \%, \mathrm{p}<0.01)$ more than in alcoholic parturient rats. SRIF-LI levels were unaffected. The inhibitory effect of SRIF on basal and forskolin-stimulated adenylyl cyclase was significantly lower in alcoholic virgin rats as compared to alcoholic parturient rats. No differences in the levels of the G inhibitory (Gi) $\alpha 1$ and Gi 2 proteins were observed among the experimental groups. These results suggest that gestation may confer partial resistance to the ethanol-induced effect on the SRIFergic system.
\end{abstract}

(C) 2005 Elsevier Inc. All rights reserved.

Keywords: Ethanol; Somatostatin; Gestation; Frontoparietal cortex; Adenylyl cyclase; Virgin rats

\footnotetext{
* Corresponding author. Tel.: +34 91 5035900x497; fax: +34 915035939.

E-mail address: vbarrios@telefonica.net (V. Barrios).
} 


\section{Introduction}

Excessive alcohol intake results in a variety of medical, psychological, and sociological disorders that have made alcoholism one of modern society's major problems (Lynskey et al., 2003). Chronic ethanol exposure can profoundly modify the structure and function of the mature central nervous system (CNS) and affect several neurotransmitter systems (Dahchour and De Witte, 2000). In this regard, we have previously reported the effects of acute and chronic ethanol administration and its withdrawal on the levels and binding of somatostatin (SRIF) in the rat brain (Barrios et al., 1990).

It is well known that maternal ethanol ingestion during pregnancy has a negative effect on offspring development both in humans and experimental animals (Olney et al., 2002). Chronic maternal ethanol consumption is associated with regional alterations in the levels of several neurotransmitters, neurotransmitter uptake, and receptor levels in the offspring (Mena et al., 1982). In this context, our group has shown that maternal ethanol ingestion modifies brain SRIF concentration and binding in the developing rat brain (Barrios et al., 1991). However, very few studies have examined the effects of ethanol consumption on the CNS of rodent dams.

The habitual parturition process in the rat is characterized by a significant increase in motor activity (Wigger et al., 1999), although the underlying mechanisms of these changes are unknown. We have shown that on the day of delivery, there is an increase in the number of SRIF receptors in the frontoparietal cortex of rat dams (Barrios et al., 1993). Since SRIF increases locomotor activity in the rat (Justino et al., 1997) and chronic ethanol ingestion decreases the number of SRIF receptors in the rat frontoparietal cortex (Barrios et al., 1990), we hypothesized that the SRIFergic system could be implicated, at least partly, in the decrease of motor activity found in parturient rats that have consumed ethanol during pregnancy.

SRIF, one of the most abundant neuropeptides in the CNS, has a role as a neurotransmitter and neuromodulator in several neurophysiological functions (Blake et al., 2004). The actions of SRIF are mediated via five heptahelical transmembrane receptors and binding of SRIF to these receptors in native membranes triggers the recruitment of a wide variety of intracellular effectors through the activation of pertussis toxin-sensitive and -insensitive $G$ proteins (Olias et al., 2004). One of the most widely studied intracellular effectors is the adenylyl cyclase (AC)-cyclic adenosine monophosphate (cAMP)-protein kinase A pathway. In the rat cerebral cortex, hippocampus and striatum, SRIF inhibits basal and stimulated cAMP production (Schettini et al., 1989). Specific G protein subunits link native SRIF receptors to AC and appear to be responsible for transducing SRIF receptor inhibition of $\mathrm{AC}$. In addition, the cAMP signalling cascade has a role in ethanol tolerance (Pandey et al., 2001).

In the present study, we tested the hypothesis that ethanol ingestion during gestation affects the SRIFergic system in the rat frontoparietal cortex of dams. Because female hormones modulate the impact of ethanol on the brain (Van Doren et al., 2000), we also compared the effects of chronic ethanol ingestion between parturient and virgin rats. The day of delivery was chosen for this study, given the modifications of female hormones found at this time-period. To this end, we examined SRIF levels, the

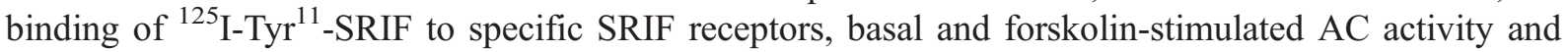
SRIF-mediated inhibition of AC activity in frontoparietal cortical membranes of alcoholic rats on the day of delivery and in normal virgin female rats. In addition, we assessed the functional activity of the guanine nucleotide-binding inhibitory protein (Gi) and determined the levels of the $\alpha \mathrm{i} 1$ and $\alpha \mathrm{i} 2 \mathrm{G}$ protein subunits. 


\section{Materials and methods}

\section{Chemicals}

Synthetic [Tyr $\left.{ }^{11}\right]$-SRIF and SRIF-14 were purchased from Universal Biological (Cambridge, UK); carrier free $\mathrm{Na}^{125} \mathrm{I}$ (IMS 30, $100 \mathrm{mCi} / \mathrm{ml}$ ) was purchased from the Radiochemical Centre (Amersham, Buckinghamshire, UK), bacitracin and bovine serum albumin (fraction V) were obtained from Sigma (St. Louis, MO, USA); and ethanol from Merck (Darmstadt, Germany). The antibody used in the radioimmunoassay technique was raised in rabbits against SRIF-14 conjugated to bovine serum albumin and is specific for SRIF. Since SRIF-14 also constitutes the COOH-terminal portion of SRIF28, the antiserum does not distinguish between these two forms. The binding of SRIF-14 to this antibody does not depend on an intact disulfide bond since reaction with $0.1 \%$ mercaptoethanol (boiling water bath, $5 \mathrm{~min}$ ) did not change the immunoreactivity of the peptide. Cross-reactivity with

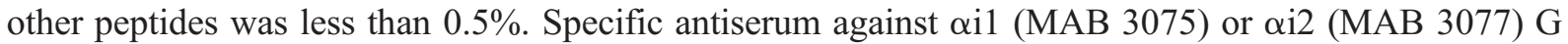
protein subunits was obtained from Chemicon International (California, USA). Nitrocellulose membranes and the chemiluminiscence western blotting detection system were purchased from Amersham (Buckinghamshire, UK).

\section{Animal treatment}

Female Sprague-Dawley rats weighing $150 \pm 10 \mathrm{~g}$ from our colony were grouped three per cage and kept under automatically controlled humidity $(65 \pm 5 \%)$, temperature $\left(22-23{ }^{\circ} \mathrm{C}\right)$, and $12: 12 \mathrm{~h}$ light-dark cycles. Daily caloric intake was estimated by the specific calorific value of the commercial Purina Chow used $(3,200 \mathrm{cal} / \mathrm{kg})$ and the amount of food consumed by the animals, which was determined by daily weighing of the offered and remaining food. The daily fluid intake was also determined by volume difference between the offered and remaining liquid, and ethanol calories were estimated as $7.1 \mathrm{kcal} / \mathrm{g}$. Twenty animals were divided into four groups ( $\mathrm{n}=5$ per group) and treated according to the following schedules (Testar et al., 1986): ethanol-treated rats received Purina Rat Chow ad libitum and 10, 15, 20 and $25 \%(\mathrm{v} / \mathrm{v})$ ethanol in their drinking water on successive weeks before pregnancy. At the end of the 4th week the animals were mated with normal males and given $25 \%$ ethanol in their drinking water during gestation. This dose of ethanol represented $30-35 \%$ of the total caloric intake. Another group of parturient rats drank only water during these same time-periods. Virgin animals received ethanol or water for equivalent time periods. Parturient and virgin control rats received a standard diet ad libitum. The parturient rats were decapitated on the day of delivery and the virgin rats at an equivalent time period. The brains were removed and the frontoparietal cortex was rapidly dissected on ice. The animal studies were carried out in accordance to the Declaration of Helsinki.

\section{Blood ethanol levels}

After decapitation, blood samples were collected from the neck wound into heparinized receptacles for immediate plasma separation. Plasma aliquots of $0.5 \mathrm{ml}$ were used for determination of ethanol by head space gas chromatography as previously described (Espinet and Argilés, 1984), using a PerkinElmer gas chromatograph (model Sigma 3B) equipped with a flame ionization detector, a head-space injection device, and a Sigma 15 integrator and recorder. 


\section{Tissue extraction and SRIF radioimmunoassay}

SRIF was extracted from frontoparietal cortical tissue in $2 \mathrm{M}$ acetic acid by homogenization and boiling and was measured by a specific radioimmunoassay (Patel and Reichlin, 1978) with a sensitivity limit of $10 \mathrm{pg} / \mathrm{ml}$. Dilution curves for frontoparietal cortical extracts were parallel to the standard curve. The intra- and interassay variation coefficients were 5.7 and $7.5 \%$, respectively.

\section{Membrane preparations}

The frontoparietal cortex was homogenized in $10 \mathrm{mM}$ HEPES-KOH buffer, $\mathrm{pH} 7.6$ (10 wt/vol), with a Brinkmann polytron homogenizer (setting 5, $15 \mathrm{~s}$ ). The homogenate was spun at $600 \mathrm{~g}$ for 5 min at $4^{\circ} \mathrm{C}$, and the supernatant was centrifuged at $48000 \mathrm{~g}$ for $30 \mathrm{~min}$ at $4{ }^{\circ} \mathrm{C}$. The resulting pellet was suspended in $10 \mathrm{mM}$ HEPES-KOH, pH $7.6(10 \% \mathrm{w} / \mathrm{v})$ and then centrifuged as before. The resultant pellet was resuspended in $50 \mathrm{mM}$ Tris- $\mathrm{HCl}$ buffer $(\mathrm{pH} 7.5)$. Samples were stored at $-70{ }^{\circ} \mathrm{C}$ until the day of assay.

\section{Binding assay}

$\left[\mathrm{Tyr}^{11}\right.$ ]-SRIF was radioiodinated by the chloramine-T method (Greenwood et al., 1963). The tracer was purified in a Sephadex G-25 coarse column $(1 \times 100 \mathrm{~cm})$ that had been equilibrated with $0.1 \mathrm{M}$ acetic acid containing $0.1 \%$ bovine serum albumin $(\mathrm{w} / \mathrm{v})$. The specific radioactivity of the tracer was about $600 \mathrm{Ci} / \mathrm{mmol}$.

Specific SRIF binding was measured according to the modified method of Czernik and Petrack (1983). Frontoparietal cortical membranes $(0.15 \mathrm{mg}$ protein $/ \mathrm{ml})$ were incubated in $250 \mu \mathrm{l}$ of a medium containing $50 \mathrm{mM}$ Tris- $\mathrm{HCl}$ buffer $(\mathrm{pH} 7.5), 5 \mathrm{mM} \mathrm{MgCl}_{2}, 0.2 \%(\mathrm{w} / \mathrm{v})$ bovine serum albumin and 0.1 $\mathrm{mg} / \mathrm{ml}$ bacitracin with $250 \mathrm{pM}$ of ${ }^{125} \mathrm{I}_{-}\left[\mathrm{Tyr}^{11}\right]$-SRIF in either the absence or presence of $0.01-10 \mathrm{nM}$ unlabelled SRIF. After a 60 -min incubation at $30{ }^{\circ} \mathrm{C}$, the free radioligand was separated from the bound radioligand by centrifugation at $12000 \mathrm{~g}$ for $1.5 \mathrm{~min}$, and the resultant pellet was counted in a Beckman gamma counter. Nonspecific binding, i.e., binding occurring in the presence of a high concentration $\left(10^{-7} \mathrm{M}\right)$ of unlabeled SRIF, represented $\sim 20 \%$ of the binding observed in the absence of the native peptide and was substracted from the total bound radioactivity in order to obtain the corresponding specific binding. The inactivation of ${ }^{125} \mathrm{I}-\left[\mathrm{Tyr}^{11}\right]$-SRIF in the incubation medium after exposure to membranes was studied by observing the ability of the peptide to rebind to fresh membranes.

\section{Adenylyl cyclase assay}

For AC activity measurement, frontoparietal cortical membranes $(60 \mu \mathrm{g} / \mathrm{ml})$ were incubated with 1.5 $\mathrm{mM}$ ATP, $5 \mathrm{mM} \mathrm{MgSO} 4,10 \mu \mathrm{M}$ GTP, an ATP-regenerating system $(7.5 \mathrm{mg} / \mathrm{ml}$ creatin phosphate and 1 $\mathrm{mg} / \mathrm{ml}$ creatine kinase), $1 \mathrm{mM}$ 3-isobutyl-1-methylxanthine, $0.1 \mathrm{mM}$ phenylmethylsulfonyl fluoride, 1 $\mathrm{mg} / \mathrm{ml}$ bacitracin, $1 \mathrm{mM}$ EDTA, and test substances $\left(10^{-4} \mathrm{M}\right.$ SRIF or $10^{-5} \mathrm{M}$ forskolin) in $100 \mu \mathrm{l}$ of $0.025 \mathrm{M}$ Tris- $\mathrm{HCl}$ buffer ( $\mathrm{pH}$ 7.4). After a $15 \mathrm{~min}$ incubation at $30{ }^{\circ} \mathrm{C}$, the reaction was stopped by heating the mixture for $3 \mathrm{~min}$. After cooling, $200 \mu \mathrm{l}$ of an alumina slurry $(0.75 \mathrm{~g} / \mathrm{ml}$ in Tris- $\mathrm{HCl}$ buffer, 
$\mathrm{pH}$ 7.4) were added and the suspension was centrifuged. The supernatant was taken for assay of cAMP by the method of Gilman (1970).

\section{Immunodetection of $\alpha_{i}$ subunits of $G$ proteins}

Purified cell membranes $(100 \mu \mathrm{g})$ were solubilized in SDS-sample buffer. The proteins were then run on a $12 \%$ SDS-polyacrilamide gel. The transfer of proteins to nitrocellulose membranes and the immunodetection of the ail or ai2 subunits of the $G$ proteins using the specific mouse anti-Goi monoclonal antibodies MAB3075 and MAB3077, respectively, were carried out as described elsewhere (Mumby et al., 1986). Briefly, after protein transfer, the nitrocellulose membranes were preincubated with blocking buffer $(50 \mathrm{mM}$ Tris- $\mathrm{HCl} \mathrm{pH} 7.5,150 \mathrm{mM} \mathrm{NaCl}$, $0.05 \%(\mathrm{v} / \mathrm{v})$ Tween-20, and 5\% (w/v) non-fat dry milk). Antisera were diluted in the same buffer (dilution 1:1000) and the nitrocellulose membranes incubated overnight at $4{ }^{\circ} \mathrm{C}$. After washing, the nitrocellulose membranes were incubated with horseradish-peroxidase conjugated goat anti-mouse

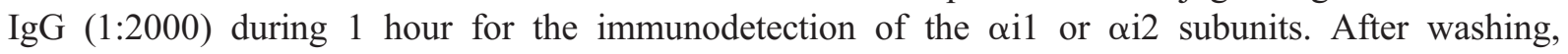
the bound immunoreactive proteins were detected by a chemiluminescent western blotting detection system.

\section{Statistical analysis}

The computer program Ligand was used to analyze the binding data. The use of this program enabled models of receptors, which best fit a given set of binding data to be selected. The same program was also used to present data in the form of Scatchard plots and to compute values for receptor affinity $\left(\mathrm{K}_{\mathrm{d}}\right)$ and density $\left(\mathrm{B}_{\max }\right)$ that best fit the sets of binding data for each rat. Statistical comparison to assess a possible interaction between the effects of ethanol treatment and the gestational state was performed by two-way analysis of variance (ANOVA). Statistical analysis of all data was carried out by one-way ANOVA and the Students Newman-Keuls test. Mean values were considered significantly different when the $p$ values were less than 0.05. Each individual experiment was performed in duplicate.

\section{Results}

Blood ethanol levels

Ethanol concentrations at the time that the rats were killed were $29.8 \pm 4.6$ and $27.0 \pm 4.9 \mathrm{mmol} / \mathrm{l}$ in virgin and parturient ethanol-treated rats, respectively.

Daily food intake, body weight and caloric intake

Average daily food intake was $7.69 \pm 0.16,5.48 \pm 0.12,7.61 \pm 0.30$ and $4.68 \pm 0.25 \mathrm{~g} / 100 \mathrm{~g}$ body weight in virgin controls, virgin ethanol-treated rats, parturient controls and parturient-treated rats, respectively $(\mathrm{p}<0.01$ vs respective control group). Body weight at the end of the study was $230 \pm 5,214 \pm 4,348 \pm 10$ and $276 \pm 8$ in the same experimental groups $(\mathrm{p}<0.01$ vs respective 
control group). However, daily caloric intake revealed no significant differences among the experimental groups.

\section{Effects of chronic ethanol ingestion on SRIF receptors}

Preliminary experiments confirmed that the specific binding of ${ }^{125} \mathrm{I}-\left[\mathrm{Tyr}^{11}\right]$-SRIF to frontoparietal cortical membranes changed linearly with protein concentration and was time-dependent in all experimental groups. An apparent equilibrium was observed between 50 and $180 \mathrm{~min}$ at $30{ }^{\circ} \mathrm{C}$ (data not shown). All subsequent binding experiments were therefore conducted at $30{ }^{\circ} \mathrm{C}$ for $60 \mathrm{~min}$. Frontoparietal cortical membranes from all experimental groups showed a similar peptide degradation capacity and the values varied by no more than $10 \%$ in all groups.

Two-way ANOVA indicated that ethanol treatment decreases the SRIF receptor density with different degrees of intensity in parturient and virgin rats $(\mathrm{p}<0.05)$. Ethanol ingestion before and during pregnancy decreased the number of SRIF receptors $(25 \%, \mathrm{p}<0.01$ vs control parturient rats) in the frontoparietal cortex on the day of delivery. The affinity of the SRIF receptors was consistently unchanged (Table 1, Fig. 1). Chronic ethanol ingestion in virgin rats decreased the number of SRIF receptors $(42 \%, \mathrm{p}<0.01)$ in the frontoparietal cortex with respect to control virgin rats. The affinity of the SRIF receptors was unchanged (Table 1, Fig. 1).

\section{Ethanol-induced effects on SRIF-LI content}

Ethanol ingestion before and during pregnancy restored the SRIF-LI levels in the frontoparietal cortex seen in control parturient rats (Fig. 2). In contrast, chronic ethanol ingestion in virgin rats did not modify SRIF-LI levels with respect to control virgin rats (Fig. 2).

\section{Ethanol ingestion decreases SRIF-mediated inhibition of AC activity}

Since SRIF receptors are coupled to AC in an inhibitory fashion, resulting in a decrease in the second messenger cAMP, we examined basal and forskolin-stimulated AC activity, as well as SRIFmediated inhibition of the enzyme in frontoparietal cortical membranes. The capacity of SRIF to inhibit both basal and forskolin-stimulated AC activity was reduced in frontoparietal cortical

Table 1

Effects of ethanol on the equilibrium parameters for binding of ${ }^{125} \mathrm{I}-\left[\mathrm{Tyr}^{11}\right]$-somatostatin to membranes from the frontoparietal cortex of virgin control, virgin ethanol-treated, parturient control and parturient ethanol-treated rats

\begin{tabular}{llll}
\hline & $\mathrm{K}_{\mathrm{d}}$ & $\mathrm{B}_{\max }$ & Decrease of SRIF receptors \\
\hline Virgin control & $0.40 \pm 0.04$ & $404 \pm 18$ & $42 \pm 3 \%$ \\
Virgin ethanol & $0.43 \pm 0.08$ & $233 \pm 20^{\mathrm{a}}$ & \\
Parturient control & $0.55 \pm 0.19$ & $629 \pm 51$ & $25 \pm 3 \%{ }^{\# \#}$ \\
Parturient ethanol & $0.53 \pm 0.06$ & $471 \pm 32^{\mathrm{a}}$ & 25 \\
\hline
\end{tabular}

Binding parameters were obtained by Scatchard analysis. $K_{d}$ is the dissociation constant expressed in $n M$; $B_{\max }$ is the maximum binding capacity expressed in fmol/mg protein. Each value is the mean \pm S.E.M. of five assays performed in duplicate.

${ }^{\mathrm{a}} \mathrm{p}<0.01$ vs respective control group.

\#\# $\mathrm{p}<0.01$ vs virgin ethanol-treated group. 


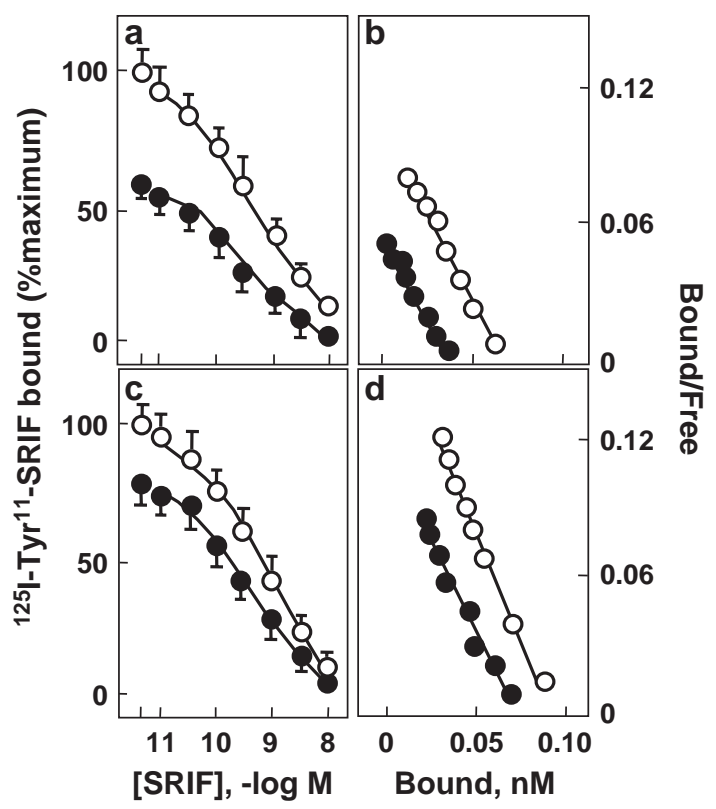

Fig. 1. A: Competitive inhibition of specific ${ }^{125} \mathrm{I}_{-}\left[\mathrm{Tyr}^{11}\right]$-somatostatin $\left({ }^{125} \mathrm{I}-\left[\mathrm{Tyr}^{11}\right]\right.$-SRIF, 250 pM) binding by unlabeled SRIF to membranes from the frontoparietal cortex of control virgin rats (open circles) and ethanol-treated virgin rats (solid circles). Each point represents the mean obtained from five rats. B: Scatchard analysis of the same data. C: Competitive inhibition of specific ${ }^{125} \mathrm{I}_{-}\left[\mathrm{Tyr}^{11}\right]$-SRIF $(250 \mathrm{pM})$ binding by unlabeled SRIF to membranes from the frontoparietal cortex of control parturient rats (open circles) and ethanol-treated parturient rats (solid circles). D: Scatchard analysis of the same data. The corresponding equilibrium binding parameters are included in Table 1.

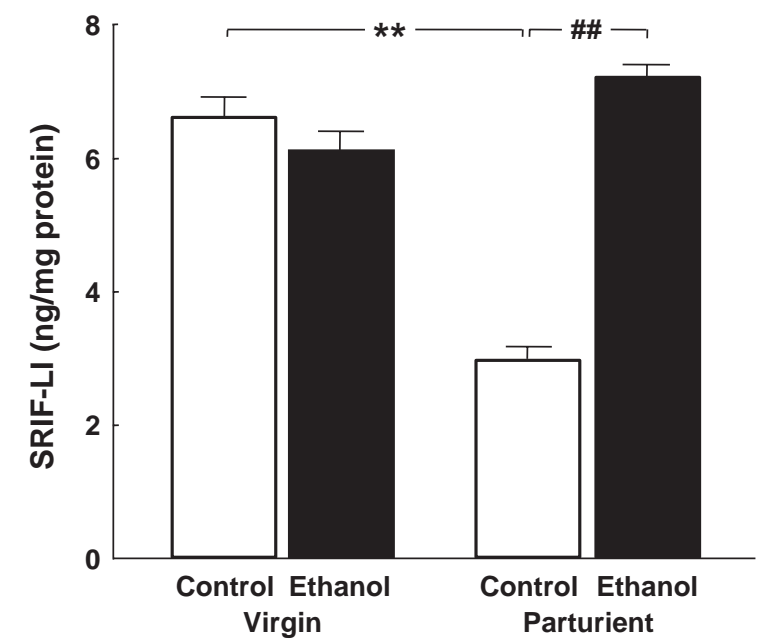

Fig. 2. Somatostatin-like immunoreactivity (SRIF-LI) content in the frontoparietal cortex from virgin and parturient control rats (open bars) and virgin and parturient ethanol-treated rats (solid bars). Values are expressed as the mean \pm S.E.M. The number of rats in each experimental group was five. ${ }^{* *} \mathrm{p}<0.01$ vs virgin control group, $\# \# \mathrm{p}<0.01$ vs parturient control group. 
Table 2

Effects of ethanol on basal and forskolin $\left(10^{-5} \mathrm{M}\right)$-stimulated adenylyl cyclase (AC) activity (pmol/min $/ \mathrm{mg}$ protein) and on SRIF $\left(10^{-4} \mathrm{M}\right)$-mediated inhibition of AC activity in frontoparietal cortical membranes of virgin control and virgin ethanoltreated rats and parturient control and parturient ethanol-treated rats

\begin{tabular}{|c|c|c|c|c|}
\hline & $\begin{array}{l}\text { Virgin } \\
\text { control }\end{array}$ & $\begin{array}{l}\text { Virgin } \\
\text { ethanol }\end{array}$ & $\begin{array}{l}\text { Parturient } \\
\text { control }\end{array}$ & $\begin{array}{l}\text { Parturient } \\
\text { ethanol }\end{array}$ \\
\hline Basal activity & $513 \pm 57$ & $471 \pm 38$ & $561 \pm 34$ & $527 \pm 50$ \\
\hline Basal activity $+10^{-4} \mathrm{M}$ SRIF & $323 \pm 28$ & $372 \pm 43$ & $331 \pm 40$ & $352 \pm 22$ \\
\hline$\%$ SRIF inhibition of basal activity & $37.1 \pm 6.8$ & $21.0 \pm 8.0^{*}$ & $40.1 \pm 6.8$ & $33.5 \pm 5.7$ \\
\hline$+10^{-5} \mathrm{M}$ forskolin & $1750 \pm 157$ & $1739 \pm 112$ & $2022 \pm 137$ & $2146 \pm 53$ \\
\hline $10^{-5} \mathrm{M}$ forskolin $+10^{-4} \mathrm{M}$ SRIF & $1196 \pm 19$ & $1354 \pm 39$ & $1389 \pm 61$ & $1618 \pm 153$ \\
\hline$\%$ SRIF inhibition of forskolin-stimulated activity & $30.1 \pm 4.9$ & $20.2 \pm 4.2 *$ & $29.3 \pm 7.4$ & $24.6 \pm 7.1$ \\
\hline Decrease of \% SRIF inhibition of basal activity & & $43.4 \%$ & & $16.5 \% * *$ \\
\hline Decrease of \% SRIF inhibition of forskolin-stimulated activity & & $32.9 \%$ & & $16.0 \% * *$ \\
\hline
\end{tabular}

Values represent the mean \pm S.E.M. The number of rats in each experimental group was five.

$* \mathrm{p}<0.05$ vs control.

** $\mathrm{p}<0.01$ vs virgin group.

membranes of virgin ethanol-treated rats to a greater extent than in alcoholic mothers on the day of delivery (Table 2), as compared to their respective control groups.

\section{Ethanol and Gi protein levels}

The next question we addressed was whether the functional capacity of the SRIF receptors was altered by ethanol ingestion. To this aim, western blot analyses of the $\alpha 1$ or $\alpha 2$ subunits of inhibitory Gi proteins were performed in frontoparietal cortical membranes. No significant differences in the levels of these protein subunits were detected between the experimental groups (data not shown).

\section{Discussion}

The present results show that ethanol ingestion during gestation impedes the decline in SRIF content caused by pregnancy and induces a decrease in the density of SRIF receptors (25\%) in the frontoparietal cortex on the day of delivery with respect to control parturient rats. The ethanol-induced decrease in the SRIF receptor density was less than that observed in virgin ethanol-treated rats (42\%).

The experimental protocol for the prolonged ethanol treatment of the parturient rat used in this study was the same as that employed by Testar et al. (1986). In this model, the percentage of ethanolderived calories and the maternal blood ethanol levels were similar to those reported when ethanol was given in a liquid diet. A control pair-fed group has not been studied, because these authors reported that pair-fed rats have a higher degree of undernutrition than alcohol-treated animals, as shown by a reduced body weight gain and less frequent viable gestations. This model induces tolerance to ethanol in alcohol-treated virgin animals, whereas no tolerance is observed in alcoholtreated parturient rats (Través and López-Tejero, 1994). Our results cannot be attributed to a possible undernutrition, because dietary restriction does not modify SRIF nor SRIF receptor expression (Shimokawa et al., 2000; Shimokawa et al., 2003). The results obtained by stoichiometric analyses 
allow us to obtain a fair estimation of the total SRIF receptor density. Thus, present-day techniques, such as in situ hybridization and quantification by western blot present a good relationship with quantification of receptor density performed by radioligand binding (Schulz et al., 2000; Fehlmann et al., 2000). Nonetheless, future experiments will be necessary in order to analyze the participation of individual SRIF receptor subtypes in the ethanol-induced effects.

This treatment has also been shown to reduce the serotonin, dopamine and acetylcholine content in different brain regions (Arendt et al., 1989). In this context, our group demonstrated that a decrease in serotoninergic transmission leads to a decrease in the SRIF receptor density and that dopamine stimulation induces a rise in the number of SRIF receptors (Rodríguez-Sánchez et al., 1997). Other factors such as GABA could be implicated in the observed decrease of SRIF receptors. Indeed, GABA is augmented in alcoholic mothers on the day of delivery (Mena et al., 1982) and stimulation of GABAergic neurotransmission decreases the number of SRIF receptors in the rat frontoparietal cortex (Martínez and Arilla, 1993).

The decrease in the number of SRIF receptors in alcoholic virgin rats with respect to control virgin rats $(42 \%)$ was greater than that found in ethanol parturient group $(25 \%)$ when compared with control parturient rats. Although the mechanism is unknown, changes in protein kinase $\mathrm{C}$ and noradrenaline in ethanol-tolerant rats may be involved. In this context, it should be noted that tolerance to ethanol was observed in ethanol-treated virgin rats, but not in ethanol-treated parturient rats (Través and LópezTejero, 1994). Chronic ethanol exposure upregulates delta and epsilon protein kinase $C$ and this kinase decreases SRIF binding (Matozaki et al., 1986). On the other hand, noradrenergic neurons have been implicated in the development of ethanol tolerance and the development of $\alpha_{2}$-adrenoceptor hyposensitivity has been postulated to occur during long-term exposure to ethanol (Verbanck et al., 1991). We have previously demonstrated that the $\alpha_{2}$-adrenoceptor antagonist yohimbine decreases the number of SRIF receptors (López-Sañudo and Arilla, 1994).

Levels of SRIF-LI are reduced in parturient rats. The mechanism of this reduction is unknown, but it has been reported that norepinephrine and serotonin stimulate brain SRIF release and both neurotransmitters rise after parturition, with a subsequent decrease of SRIF-LI levels in this period (Desan et al., 1988). Chronic ethanol consumption restored SRIF-LI content in parturient rats. In this context, it has been shown that estradiol levels are elevated in pregnant rats exposed to ethanol (HilakiviClarke et al., 2004) and this estrogen increases SRIF mRNA in the central nervous system (Pillon et al., 2004). On the other hand, GABA inhibits SRIF release and GABA content is increased on the day of delivery (Bonanno et al., 1999). Thus, SRIF release may be decreased, which would result in an increase in SRIF levels. However, chronic ethanol ingestion in virgin rats had no effect on SRIF content when compared with control virgin rats. These results are in agreement with our previous results in male rats (Barrios et al., 1990). In vitro studies have demonstrated that chronic ethanol treatment has no direct effect either on SRIF content or SRIF mRNA levels in neurons (Rage et al., 1998) and in vivo results suggest that a much longer period of alcohol consumption is necessary to diminish brain SRIF content in non-pregnant rats (Madeira et al., 1997).

Chronic ethanol ingestion decreased the capacity of SRIF to inhibit AC activity in virgin and parturient rats. These results are in agreement with those obtained by Wenrich et al. (1998) in ethanol-treated rats. In addition, the capacity of SRIF to inhibit AC activity in alcoholic virgin rats was reduced to a greater extent than in alcoholic parturient rats when compared to their control groups. This greater decrease may be related to the pronounced loss of SRIF receptors shown in this group. 
In view of these results, we examined whether ethanol ingestion during gestation could alter the levels of heterotrimeric guanine nucleotide-binding inhibitory proteins (Gi proteins). Chronic ethanol exposure did not induce significant changes in Gi proteins. These results are in agreement with other authors. Thus, long-term incubation of the NG 108-15 neuroblastoma glioma hybrid cell line with ethanol was not associated with any change in Gi $\alpha$-proteins (Charness et al., 1988). In addition, in vivo studies on chronic ethanol consumption demonstrated no changes in Gi proteins in the cerebral cortex (Tabakoff et al., 1995).

Here we show that ethanol has less effect on the frontoparietal cortical SRIFergic system and AC activity of gestational rats than that of virgin rats. In fact, ethanol has been demonstrated to induce a dose-dependent increase in lipid peroxidation in brain homogenates (Montoliu et al., 1994) and gestation to confer temporary resistance to peroxidation in the maternal rat brain (Subramanian et al., 1993). This protective effect of gestation could be responsible for the decreased toxic effects of ethanol on brain membrane alterations observed after chronic ethanol intake. Therefore, it is possible that ethanol has less effect on the SRIFergic receptor-effector system, at least in part, due to this resistance to peroxidation.

In summary, the present results suggest that gestation seems to confer partial resistance to the ethanolinduced effect on the SRIFergic receptor-effector system in the rat frontoparietal cortex.

\section{Acknowledgements}

The authors gratefully acknowledge the excellent editorial assistance of Dr. Julie A. Chowen and Dr. Karen Heath in the preparation of this manuscript. This work was supported by grants from the Ministerio de Ciencia y Tecnología (SAF 2003-08052) and Fondo de Investigación Sanitaria (PI02/1241).

\section{References}

Arendt, T., Allen, Y., Marchbanks, R.M., Schugens, M.M., Sinden, J., Lantos, P.L., Gray, J.A., 1989. Cholinergic system and memory in the rat: effects of chronic ethanol, embryonic basal forebrain, brain transplants and excitotoxic lesions of cholinergic basal forebrain projection system. Neuroscience 33 (3), 435-462.

Barrios, V., Rodríguez-Sánchez, M.N., Arilla, E., 1990. Effects of acute and chronic ethanol administration and its withdrawal on the level and binding of somatostatin in rat brain. Clinical Science 79 (5), 451-456.

Barrios, V., Rodríguez-Sánchez, M.N., Hernández, M., Arilla, E., 1991. Maternal ethanol ingestion and somatostatin level and binding in developing rat brain. American Journal of Physiology 261 (6), E758-E763.

Barrios, V., Puebla, L., Rodríguez-Sánchez, M.N., Arilla, E., 1993. Brain somatostatinergic system at late pregnancy, parturition and the early postpartum period in the rat. Regulatory Peptides 48 (3), 355-366.

Blake, A.D., Badway, A.C., Strowski, M.Z., 2004. Delineating somatostatin's neuronal actions. Current Drug Targets CNS Neurological Disorders 3 (2), 153-160.

Bonanno, G., Carita, F., Cavazzani, P., Munari, C., Raiteri, M., 1999. Selective block of rat and human neocortex GABA(B) receptors regulating somatostatin release by a GABA(B) antagonist endowed with cognition enhancing activity. Neuropharmacology 38 (11), 1789-1795.

Charness, M.E., Querimit, L.A., Henteleff, M., 1988. Ethanol differentially regulates G proteins in neural cells. Biochemical and Biophysical Research Communications 155 (1), 138-143.

Czernik, A.J., Petrack, V., 1983. Somatostatin receptor binding in rat cerebral cortex. Characterization using a nonreducible somatostatin analog. Journal of Biological Chemistry 285 (9), 5525-5530.

Dahchour, A., De Witte, P., 2000. Ethanol and aminoacids in the central nervous system: assessment of the pharmacological actions of acamprosate. Progress in Neurobiology 60 (4), 343-362. 
Desan, P.H., Woodmansee, W.W., Ryan, S.M., Smock, T.K., Maier, S.F., 1988. Monoamine neurotransmitters and metabolites during the estrous cycle, pregnancy, and the postpartum period. Pharmacology, Biochemistry and Behavior 30 (3), 563-568.

Espinet, C., Argilés, J.M., 1984. The use of thiourea in the determination of tissue ethanol and acetaldehyde concentrations. IRCS Medical Science 12, 291-292.

Fehlmann, D., Langenegger, D., Schuepbach, E., Siehler, S., Feuerbach, D., Hoyer, D., 2000. Distribution and characterisation of somatostatin receptor mRNA and binding sites in the brain and periphery. Journal of Physiology (Paris) 94 (3-4), 265-281.

Gilman, A.G., 1970. A protein binding assay for adenosine $3^{\prime} 5^{\prime}$-cyclic monophosphate. Proceedings of the National Academy of Science (USA) 67 (1), 305-312.

Greenwood, F.C., Hunter, W.M., Glover, J.S., 1963. The preparation of 131I-labeled human growth hormone of high specific radioactivity. The Biochemical Journal 89, 114-123.

Hilakivi-Clarke, L., Cabanes, A., de Assis, S., Wang, M., Khan, G., Shoemaker, W.J., Stevens, R.G., 2004. In utero alcohol exposure increases mammary tumorigenesis in rats. British Journal of Cancer 90 (11), 2225-2231.

Justino, L., Welner, S.A., Tannenbaum, G.S., Schipper, H.M., 1997. Long-term effects of cysteamine on cognitive and locomotor behavior in rats: relationship to hippocampal glial pathology and somatostatin levels. Brain Research 761 (1), $127-134$.

López-Sañudo, S., Arilla, E., 1994. Somatostatin receptors coupled to the inhibition of adenylyl cyclase in the rat frontoparietal cortex are modulated by $\alpha_{2}$ adrenoceptors. Molecular Brain Research 25 (1-2), 143-146.

Lynskey, M.T., Day, C., Hall, W., 2003. Alcohol and other drug use disorders among older-aged people. Drug and Alcohol Review 22 (2), 125-133.

Madeira, M.D., Andrade, J.P., Lieberman, A.R., Sousa, N., Almeida, O.F., Paula-Barbosa, M.M., 1997. Chronic alcohol consumption and withdrawal do not induce cell death in the suprachiasmatic nucleus, but lead to irreversible depresion of peptide immunoreactivity and mRNA levels. Journal of Neuroscience 17 (4), 1302-1319.

Martínez, A., Arilla, E., 1993. The effect of diazepam and the benzodiazepine antagonist CGS8216 on the somatostatinergic neuronal system. Neuropharmacology 32 (4), 393-399.

Matozaki, T., Sakamoto, C., Nagao, M., Baba, S., 1986. Phorbol ester or diacylglycerol modulates somatostatin binding to its receptors on rat pancreatic acinar cell membranes. Journal of Biological Chemistry 261 (3), 1414-1420.

Mena, M.A., Salinas, M., Martín del Río, R., Herrera, E., 1982. Effects of maternal ethanol ingestion on cerebral neurotransmitters and cyclic-AMP in the rat offspring. General Pharmacology 13 (3), 241-248.

Montoliu, C., Valles, S., Renau-Piqueras, J., Guerri, C., 1994. Ethanol-induced oxygen radical formation and lipid peroxidation in rat brain: effect of chronic alcohol consumption. Journal of Neurochemistry 63 (5), 1855-1862.

Mumby, S.M., Kahn, R.A., Manning, D.R., Gilman, A.G., 1986. Antisera of designed specificity for subunits of guanine nucleotide-binding regulatory proteins. Proceedings of the National Academy of Science (USA) 83 (2), $265-269$.

Olias, G., Viollet, C., Kusserow, H., Epelbaum, J., Meyerhof, W., 2004. Regulation and function of somatostatin receptors. Journal of Neurochemistry 89 (5), 1057-1091.

Olney, J.W., Wozniak, D.F., Farber, N.B., Jevtovic-Todorovic, V., Bittigan, P., Ikonomidou, C., 2002. The enigma of fetal alcohol neurotoxicity. Annals of Medicine 34 (2), 109-119.

Pandey, S.C., Saito, T., Yoshimura, M., Sohma, H., Gotz, M.E., 2001. cAMP signaling cascade: a promising role in ethanol tolerance and dependence. Alcoholism and Clinical Experimental Research 25 (Suppl 5), 46S-48S.

Patel, Y.C., Reichlin, S., 1978. Somatostatin in hypothalamus, extrahypothalamic brain and peripheral tissues of the rat. Endocrinology 102 (2), 523-530.

Pillon, D., Caraty, A., Fabre-Nys, C., Lomet, D., Cateau, M., Bruneau, G., 2004. Regulation by estradiol of hypothalamic somatostatin gene expression: possible involvement of somatostatin in the control of luteinizing hormone secretion in the ewe. Biology of Reproduction 71 (1), 38-44.

Rage, F., Arancibia, S., Tapia-Arancibia, L., 1998. Effect of acute, but not chronic ethanol treatment on somatostatin secretion in rat hypothalamic neurons. Neuroscience Letters 245 (3), 175-179.

Rodríguez-Sánchez, M.N., Puebla, L., López-Sañudo, S., Puebla, L., Rodríguez-Martín, E., Martín-Espinosa, A., RodríguezPena, M.S., Juarranz, M.G., Arilla, E., 1997. Dopamine enhances somatostatin receptor-mediated inhibition of adenylate cyclase in rat striatum and hippocampus. Journal of Neuroscience Research 48 (3), 238-248.

Schettini, G., Florio, T., Meucci, O., Landolfi, E., Grimaldi, M., Ventra, C., Marino, A., 1989. Somatostatin inhibition of adenylate cyclase activity in different brain areas. Brain Research 492 (1-2), 65-71. 
Schulz, S., Händel, M., Schreff, M., Schmidt, H., Höllt, V., 2000. Localization of five somatostatin receptors in the rat central nervous system using subtype-specific antibodies. Journal of Physiology (Paris) 94 (3-4), 259-264.

Shimokawa, I., Fukuyama, T., Yanagihara-Outa, K., Tomita, M., Komatsu, T., Higami, Y., Tuchiya, T., Chiba, T., Yamaza, Y., 2003. Effects of caloric restriction on gene expression in the arcuate nucleus. Neurobiology of Aging 24 (1), $117-123$.

Shimokawa, I., Yanagihara, K., Higami, Y., Okimoto, T., Tomita, M., Ikeda, T., Lee, S., 2000. Effects of aging and dietary restriction on mRNA levels of receptors for growth hormone-releasing hormone and somatostatin in the rat pituitary. The Journals of Gerontology. Series A, Biological Sciences and Medical Sciences 55 (6), B274-B279.

Subramanian, M., Pusphendran, C.K., Tarachand, U., Devasagayam, T.P.A., 1993. Gestation confers temporary resistance to peroxidation in the maternal rat brain. Neuroscience Letters 155 (2), 151-154.

Tabakoff, B., Whelan, J.P., Ovchinnikova, L., Nhamburo, P., Yoshimura, M., Hoffman, P.L., 1995. Quantitative changes in G proteins do not mediate ethanol-induced downregulation of adenylyl cyclase in mouse cerebral cortex. Alcoholism and Clinical Experimental Research 19 (1), 187-194.

Testar, W., López, D., Llobera, M., Herrera, E., 1986. Ethanol administration in the drinking fluid to parturient rats as a model for the fetal alcohol syndrome. Pharmacology, Biochemistry and Behavior 24 (3), 625-630.

Través, C., López-Tejero, D., 1994. Ethanol elimination in alcohol-treated parturient rats. Alcohol and Alcoholism 29 (4), 385-395.

Van Doren, M.J., Matthews, D.B., Janis, G.C., Grobin, A.C., Devaud, L.L., Morrow, A.L., 2000. Neuroactive steroid $3 \alpha-$ hydroxy-5 $\alpha$-pregnan-20-one modulates electrophysiological and behavioral actions of ethanol. Journal of Neuroscience 20 (5), 1982-1989.

Verbanck, P., Seutin, V., Massotte, L., Dresse, A., 1991. Yohimbine can induce ethanol tolerance in an in vitro preparation of rat locus coeruleus. Alcoholism and Clinical Experimental Research 15 (6), 1036-1039.

Wenrich, D., Lichtenberg-Kraag, B., Rommelspacher, H., 1998. G protein pattern and adenylyl cyclase activity in the brain of rats after long-term ethanol. Alcohol 16 (4), 285-293.

Wigger, A., Oehler, I., Lörscher, P., Keck, M., Naruo, T., Neumann, I.D., 1999. Non-responsiveness of the HPA axis to parturition-related events in the rat: involvement of endogenous opioids. Endocrinology 140 (6), 2843-2849. 